\title{
Problems of mini-pig breeding
}

\author{
K.S. Shatokhin \\ Novosibirsk State Agrarian University, Novosibirsk, Russia \\ ه true_genetic@mail.ru
}

\begin{abstract}
This article provides an overview of some problems of the breeding and reproduction of laboratory minipigs. The most obvious of these are the lack of centralized accounting of breeding groups, uniform selection standards for reproduction and evaluation of breeding animals, as well as minimizing the accumulation of fitness-reducing mutations and maintaining genetic diversity. According to the latest estimates, there are at least 30 breeding groups of mini-pigs systematically used as laboratory animals in the world. Among them, there are both breed formations represented by several colonies, and breeding groups consisting of a single herd. It was shown that the main selection strategy is selection for the live weight of adults of $50-80 \mathrm{~kg}$ and the adaptation of animals to a specific type of biomedical experiments. For its implementation in the breeding of foreign mini-pigs, selection by live weight is practiced at 140- and 154-day-old age. It was indicated that different herds of mini-pigs have their own breeding methods to counteract inbred depression and maintain genetic diversity. Examples are the maximization of coat color phenotypes, the cyclical system of matching parent pairs, and the structuring of herds into subpopulations. In addition, in the breeding of foreign mini-pigs, molecular genetic methods are used to monitor heterozygosity. Every effort is made to keep the number of inbred crosses in the breeding of laboratory mini-pigs to a minimum, which is not always possible due to their small number. It is estimated that to avoid close inbreeding, the number of breeding groups should be at least 28 individuals, including boars of at least 4 genealogical lines and at least 4 families of sows. The accumulation of genetic cargo in herds of mini-pigs takes place, but the harmful effect is rather the result of erroneous decisions of breeders. Despite the fact that when breeding a number of mini-pigs, the goal was to complete the herds with exclusively white animals, in most breeding groups there is a polymorphism in the phenotype of the coat color. Key words: laboratory mini-pigs; inbreeding; genetic diversity; recessive mutations; selection; lines; families; agriculture.
\end{abstract}

For citation: Shatokhin K.S. Problems of mini-pig breeding. Vavilovskii Zhurnal Genetiki i Selektsii=Vavilov Journal of Genetics and Breeding. 2021;25(3):284-291. DOI 10.18699/VJ21.032

\section{Проблемы селекции лабораторных мини-свиней}

\author{
К.С. Шатохин \\ Новосибирский государственный аграрный университет, Новосибирск, Россия \\ ه true_genetic@mail.ru
}

\begin{abstract}
Аннотация. В статье представлен обзор проблем разведения и селекции лабораторных мини-свиней. Наиболее очевидные из них - отсутствие централизованного учета селекционных групп, единых стандартов отбора для воспроизводства и оценки племенных животных, а также минимизация накопления снижающих приспособленность мутаций и поддержание генетического разнообразия. По последним данным, в мире насчитывают не менее 30 селекционных групп мини-свиней, систематически используемых в качестве лабораторных животных. Среди них существуют как породные образования, представленные несколькими колониями, так и селекционные группы, состоящие из одного стада. Показано, что основная стратегия отбора включает селекцию на живую массу взрослых особей 50-80 кг и приспособленность животных к конкретному типу биомедицинских экспериментов. Для ее реализации в разведении зарубежных мини-свиней практикуют отбор по живой массе в 140- и 154-дневном возрасте. Указано, что в стадах мини-свиней представлены разные селекционные методы противодействия инбредной депрессии и поддержания генетического разнообразия. Примерами служат максимизация фенотипов масти, цикличная система подбора родительских пар и структурирование стад на субпопуляции. Кроме того, в разведении зарубежных мини-свиней для мониторинга гетерозиготности используют молекулярно-генетические методы. Количество инбредных скрещиваний в разведении лабораторных мини-свиней стараются минимизировать, что не всегда возможно из-за их малочисленности. Подсчитано, что во избежание тесного инбридинга численность селекционной группы должна быть не менее 28 особей, включающих хряков как минимум четырех генеалогических линий и свиноматок из не менее четырех семейств. Накопление генетического груза в стадах мини-свиней возможно, но вредоносный эффект является скорее следствием ошибочных решений селекционеров. Несмотря на то что при выведении ряда мини-свиней стояла цель укомплектовать стада исключительно белыми животными, в большинстве селекционных групп наблюдается полиморфизм по фенотипу масти.

Ключевые слова: лабораторные мини-свиньи; инбридинг; генетическое разнообразие; рецессивные мутации; отбор; линии; семейства; сельское хозяйство.
\end{abstract}




\section{Background}

Despite the practicality of laboratory use in comparison with primates and several morphophysiological advantages over other laboratory animals (Tikhonov, 2010; Shatokhin et al., 2019), mini-pigs are still not the most popular biological model, second not only to rodents but also to dogs, cats and monkeys (Heining, Ruysschaert, 2016). However, according to various estimates, there are from 21 to 45 breeding groups of mini-pigs globally (Smith, Swindle, 2006; Köhn, 2011), of which two are bred in Russia (Stankova et al., 2017; Shatokhin et al., 2019). Although, despite the importance of understanding the breeding of any animal species, regardless of their use, the problems of breeding laboratory mini-pigs are shown in a fairly small number of scientific papers. The apparently insufficient attention to the breeding and selection of mini-pigs resulted in some problems and the lack of a unified concept for their solution. The main ones are:

1) the lack of centralized accounting of the number of laboratory mini-pigs and the registration system of specialized herds as breeding achievements;

2) the lack of generally accepted standards for the selection of animals for reproduction. This also includes the lack of regulatory documents for the evaluation of breeding animals;

3) maximizing herds' genetic diversity under conditions of gene pool depletion vectors (gene drift, bottleneck effect), optimization of monitoring and selection management methods;

4) minimizing the accumulation of fitness-reducing mutations;

5) the creation of herds of laboratory mini-pigs, staffed exclusively from animals of white coat color;

The purpose of this paper is to describe the listed problems and suggest some ways to solve them.

\section{The global genetic fund of laboratory mini-pigs}

To date, it is difficult to estimate the number of the world's population of laboratory mini-pigs and the exact number of their breeds, herds, and breeding groups. The main difficulty lies in the absence of a single body for recording laboratory mini-pigs as objects of breeding. For example, according to Russian legislation, the registration of laboratory mini-pigs is difficult due to their formal non-compliance with the criteria for evaluating breeds and breed groups of pigs as breeding achievements, particularly according to the uniformity of the breeding stock (Method of testing for distinctness..., 2007). No special standards have been developed for them. Registration is possible on the website of the American Mini-pig Association (https://americanminipigassociation.com). However, out of 14 registered breeds, only four breeding groups were reliably used as laboratory animals.

The only available accounting tool is scientific publications, but the number of breeding groups of laboratory mini-pigs varies from 21 to 45 (Smith, Swindle, 2006; Tikhonov, 2010). One of the reasons for the discrepancy in the calculation results is the presence of more than one name for the same breed formation. Our own count of laboratory mini-pigs indicated 31 breeding groups in the world (Table 1). Both breed forma- tions are represented by several colonies (Hormel, Hanford, Göttingen, NIH, Yucatan) and breeding groups consisting of a single herd (NIBS; mini-pigs of the Institute of Cytology and Genetics SB RAS, ICG SB RAS; Svetlogorsk). Representatives of the species Sus scrofa L. were taken into account with a live weight of no more than $150 \mathrm{~kg}$ and an indication of systematic use as a model object over the past 10 years.

\section{Selection principles of breeding animals}

In the breeding of laboratory mini-pigs, there are two main selection vectors: for small size and low live weight and suitability for laboratory use. However, in the breeding of minipigs, there are no uniform specially developed standards for evaluating animals by live weight at an early age, exterior, coat color and a set of characteristics necessary for use in the most common types of biomedical experiments (Helke et al., 2016). Simultaneously, almost every herd has a systematic approach to breeding with its own specific methods (Itoh et al., 2016; Nikitin et al., 2018). Animals are often evaluated at an early age, for example, 140-154 days (Miniature Swine Book of Normals, 2019; Simon, 2019). Some private farms practice selection of the smallest animals from each nest ${ }^{1}$, which in the defunct selection group Minisibs had such consequences as lowering the safety of piglets, sexual activity of boars and destroying the complex of maternal qualities of sows (Nikitin et al., 2014).

The only general principle is selecting the most robust, healthy and proportionally developed animals with a live weight of adults from 50 to $80 \mathrm{~kg}$ (Nunoya et al., 2007; Tikhonov2010; Miniature Swine Book of Normals, 2019). Vietnamese mini-pigs' exterior traits such as a weak back or early obesity are not welcomed by Russian, European and American specialists. Russian mini-pigs and several foreign breeding groups meet the accepted standards, but there are deviations, both in larger and smaller directions (Table 2). Recently, the breeding of herds of tiny pigs weighing 30 $50 \mathrm{~kg}$, for example, German mini-pigs Aachen, American Panepinto and Korean Micro-Pig ${ }^{\circledR}$, is gaining popularity (see Table 2).

\section{The preservation of genetic diversity}

The problem of preserving genetic diversity in populations is one of the most discussed issues in animal genetics (Peripolli et al., 2017; Mable, 2019) and, for several reasons, is particularly relevant for laboratory mini-pigs. The first reason is the low population of herds. The risk of depletion of the gene pool due to stochastic processes is significantly higher than in large structured subpopulations communities (Mariani et al., 2020). The second reason is the existence of several breeding groups of laboratory mini-pigs in the singular, which deprives them of such a powerful resource for controlling heterozygosity as the periodic exchange of the gene pool between different herds (Mariani et al., 2020). The third reason is that creating new herds of laboratory mini-pigs from a small number of progenitors (see Table 1) creates a risk of depleting the gene

\footnotetext{
Erasmus D. Pigs as pets: Breeding teacup pigs. Farmer's Weekly. 2013. https:// www.farmersweekly.co.za/animals/pigs-as-pets-breeding-teacup-pigs/
} 
Table 1. List of the breeding groups of laboratory mini-pigs

\begin{tabular}{|c|c|c|c|c|}
\hline No. & Name & Origin & Time and place of origin & Literature source \\
\hline 1 & Aachen & $\begin{array}{l}\text { Mini-Lewe } \times \text { Vietnamese } \\
\text { potbelly pig } \times \text { Schwäbisch } \\
\text { Hällisch Landpig } \times \text { Hormel }\end{array}$ & $\begin{array}{l}\text { Rheinisch Westfälische Technische Hochschule } \\
\text { (RWTH Aachen University), Germany }\end{array}$ & Pawlowsky et al., 2017 \\
\hline 2 & Bama & Native small breed & China & Zhang et al., 2016 \\
\hline 3 & Banna & Native small breed & China & Xin et al., 2013 \\
\hline 4 & $\mathrm{Br} 1$ & Hormel & 1964, Universidade de Sao Paolo, Brasil & Scheffer et al., 2013 \\
\hline 5 & $\begin{array}{l}\text { Clawn Miniature } \\
\text { Swine }\end{array}$ & $\begin{array}{l}\text { Göttingen } \times \text { Ohminy } \times \\
\text { Large white } \times \text { Landrace }\end{array}$ & $\begin{array}{l}\text { 1978, CLAWN Institute, Kagoshima University, } \\
\text { Japan }\end{array}$ & Köhn, 2011 \\
\hline 6 & Diannan & Native small breed & Yunnan Agricultural University, China & Cheng et al., 2016 \\
\hline 7 & Fuji Micra Inc. & $\begin{array}{l}\text { Other mini-pigs } \\
\text { (not specified) }\end{array}$ & 2009, Miyahara, Fujinomiya, Shizuoka, Japan & Maeda et al., 2016 \\
\hline 8 & Göttingen & $\begin{array}{l}\text { Vietnamese potbelly } \\
\text { pigs (gray) } \times \text { Hormel } \times \\
\text { Vietnamese native spotted } \times \\
\text { Landrace }\end{array}$ & 1960-1964, Göttingen University, Germany & Simon, 2019 \\
\hline 9 & Guizhou & Native small breed & $\begin{array}{l}\text { Laboratory Animal Center of Chongqing Medical } \\
\text { University, Chongqing, China }\end{array}$ & Xia et al., 2014 \\
\hline 10 & Hanford & Palose $\times$ Pitman-Moore & $\begin{array}{l}\text { 1958, Hanford laboratory, Washington, } \\
\text { United States }\end{array}$ & Köhn, 2011 \\
\hline 11 & $\begin{array}{l}\text { Hormel (Sinclair, } \\
\text { Minnesota) }\end{array}$ & $\begin{array}{l}\text { Piney Wood } \times \text { Ras-n-Lansa } \times \\
\text { Catalina } \times \text { Guam }\end{array}$ & $\begin{array}{l}\text { 1949, Hormel Institute, Minnesota University, } \\
\text { United States }\end{array}$ & $\begin{array}{l}\text { Köhn, 2011; } \\
\text { Miniature Swine Book } \\
\text { of Normals, } 2019\end{array}$ \\
\hline 12 & KCG & $\begin{array}{l}\text { Kogata Chinese } \times \text { Clawn } \times \\
\text { Göttingen }\end{array}$ & $\begin{array}{l}\text { 1991, National Livestock Breeding Center, Ibaraki } \\
\text { Station, Independent Administration Institution } \\
\text { of Japan, Japan }\end{array}$ & Kobayashi et al., 2012 \\
\hline 13 & Lanyu & Native small breed & $\begin{array}{l}\text { Taitung Animal Propagation Station, Livestock } \\
\text { Research Institute, Taiwan, China }\end{array}$ & $\begin{array}{l}\text { Chu, 2010; } \\
\text { Chien et al., } 2017\end{array}$ \\
\hline 14 & Lee-Sung & Lanyu $\times$ Landrace & $\begin{array}{l}\text { 1975, Department of Animal Science } \\
\text { and Technology, National Taiwan University, } \\
\text { Taiwan }\end{array}$ & Ju et al., 2019 \\
\hline 15 & MeLiM & $\begin{array}{l}\text { Hormel } \times \text { Landrace, Large } \\
\text { White } \times \text { Cornwall } \times \\
\text { Vietnamese pigs } \times \text { Göttingen }\end{array}$ & $\begin{array}{l}\text { 1967-2000, Institute of Animal Physiology } \\
\text { and Genetics of the Academy of Sciences } \\
\text { of the Czech Republic, Libechov, Czech Republic }\end{array}$ & Horak et al., 2019 \\
\hline 16 & Mexican hairless mini & Feral hog from Mexico & - & Kobayashi et al., 2012 \\
\hline 17 & Micro-Pig ${ }^{\circledR}$ & $\begin{array}{l}\text { Native small breed } \times \text { Yucatan } \times \\
\text { Vietnamese potbellied pig } \times \\
\text { Pygmy pig } \times \text { Meishan }\end{array}$ & $\begin{array}{l}\text { Medi Kinetics Co., Ltd., Pyeongtaek, } \\
\text { Republic of Korea }\end{array}$ & Jo et al., 2017 \\
\hline 18 & Micro-Yucatan & Yucatan & 1982, Charles River Laboratories, United States & Köhn, 2011 \\
\hline 19 & $\begin{array}{l}\text { Mini-Lewe } \\
\text { (Berlin mini-pigs) }\end{array}$ & $\begin{array}{l}\text { Vietnamese Pot Belly Pigs } \times \\
\text { Saddle Back Pigs } \times \text { Landrace }\end{array}$ & $\begin{array}{l}\text { 1966, Außenstelle Lehnitz der Humboldt } \\
\text { Universität, Germany }\end{array}$ & Schachler et al., 2020 \\
\hline 20 & Mini-Pig ${ }^{\circledR}$ & Native small breed & Cronex Co., Ltd., Hwaseong, Republic of Korea & Jo et al., 2017 \\
\hline 21 & $\begin{array}{l}\text { Mini-pigs } \\
\text { of ICG SB RAS }\end{array}$ & $\begin{array}{l}\text { Large White } \times \\
\text { Svetlogorsk } \times \text { Landrace } \times \\
\text { Vietnamese native breed }\end{array}$ & $\begin{array}{l}\text { 1990-1992, Institute of Cytology and Genetics } \\
\text { SB RAS (ICG SB RAS), Novosibirsk region, Russia }\end{array}$ & Nikitin et al., 2014 \\
\hline 22 & $\begin{array}{l}\text { Munich miniature } \\
\text { (Troll) }\end{array}$ & $\begin{array}{l}\text { Hanford } \times \text { Columbian Miniature } \\
\text { Swine }\end{array}$ & 1993, Munich, Germany & $\begin{array}{l}\text { Köhn, 2011; } \\
\text { Bourneuf, } 2017\end{array}$ \\
\hline 23 & NIBS & $\begin{array}{l}\text { Pitman-Moore } \times \text { Taiwanese } \\
\text { small-ear pigs } \times \text { Göttingen }\end{array}$ & $\begin{array}{l}\text { 1993, Nippon Institute for Biological Science, } \\
\text { Tokyo, Japan }\end{array}$ & Yoshimatsu et al., 2016 \\
\hline
\end{tabular}


Table 1 (end)

\begin{tabular}{|c|c|c|c|c|}
\hline No. & Name & Origin & Time and place of origin & Literature source \\
\hline 24 & $\mathrm{NIH}$ & $\begin{array}{l}\text { Feral hog from Indiana state } \times \\
\text { Hanford }\end{array}$ & $\begin{array}{l}\text { 1972, National Institute of Health, Bethesda, } \\
\text { Maryland, United States }\end{array}$ & $\begin{array}{l}\text { Sachs et al., 1976; } \\
\text { Nicholls et al., } 2012\end{array}$ \\
\hline 25 & Ossabaw & Feral hog from Ossabaw island & 2001-2002, Indiana University, United States & $\begin{array}{l}\text { McKenney-Drake } \\
\text { et al., } 2016\end{array}$ \\
\hline 26 & Panepinto & Yucatan $\times$ Vietnamese & 1990, Colorado State University, United States & Köhn, 2011 \\
\hline 27 & Pitman-Moore & Feral hog from Florida state & $\begin{array}{l}\text { 1969, Pitman-Moore Pharmaceutical Company, } \\
\text { Indianapolis, United States }\end{array}$ & Val-Laillet et al., 2013 \\
\hline 28 & Svetlogorsk & Minisib × Göttingen & $\begin{array}{l}\text { 1974, Scientific Center of Biomedical Technologies, } \\
\text { Moscow region, Russia }\end{array}$ & Stankova et al., 2017 \\
\hline 29 & Westran & Feral hog from Kangaroo island & $\begin{array}{l}\text { 1976, Commonwealth Scientific and Research } \\
\text { Organization, Australia }\end{array}$ & Köhn, 2011 \\
\hline 30 & Wuzhishan & Native small breed & $\begin{array}{l}\text { 1990, Wuzhishan pig breeding farm of Academy } \\
\text { of Agricultural Sciences, Hainan province, China }\end{array}$ & Song et al., 2014 \\
\hline 31 & Yucatan & Feral hog from Mexico & 1960, Colorado StateUniversity, United States & $\begin{array}{l}\text { Miniature Swine Book } \\
\text { of Normals, } 2019\end{array}$ \\
\hline
\end{tabular}

Table 2. Live weight of adult laboratory mini-pigs from different breeding groups

\begin{tabular}{|c|c|c|}
\hline Breeding group & $\begin{array}{l}\text { Live } \\
\text { weight, kg }\end{array}$ & Literature source \\
\hline Aachen & $45-50$ & Pawlowsky et al., 2017 \\
\hline Bama & $\sim 50$ & Zhang et al., 2016 \\
\hline $\mathrm{Br} 1$ & $30-70$ & Mariano, 2003 \\
\hline Clawn & $\sim 40$ & Köhn, 2011 \\
\hline Göttingen & $25-50$ & Simon, 2019 \\
\hline Hanford & $80-95$ & Köhn, 2011 \\
\hline Hormel & $55-70$ & $\begin{array}{l}\text { Miniature Swine Book } \\
\text { of Normals, } 2019\end{array}$ \\
\hline Micro-Pig ${ }^{\circledR}$ & $30-35$ & Jo et al., 2017 \\
\hline Micro-Yucatan & $55-70$ & Köhn, 2011 \\
\hline Mini-Lewe & $45-60$ & Schachler et al., 2020 \\
\hline Mini-Pig ${ }^{\circledR}$ & $57-64$ & Jo et al., 2017 \\
\hline Mini-pigs of ICG SB RAS & $60-70$ & Shatokhin et al., 2019 \\
\hline Munich miniature (Troll) & $60-100$ & $\begin{array}{l}\text { Köhn, 2011; } \\
\text { Bourneuf, } 2017\end{array}$ \\
\hline Ossabaw & $72-116$ & $\begin{array}{l}\text { McKenney-Drake et al., } \\
2016\end{array}$ \\
\hline Panepinto & $25-30$ & Köhn, 2011 \\
\hline Pitman-Moore & $40-69$ & Tikhonov, 2010 \\
\hline Svetlogorsk & $35-50$ & Stankova et al., 2017 \\
\hline Westran & $80-93$ & Köhn, 2011 \\
\hline Wuzhishan & $35-40$ & Song et al., 2014 \\
\hline Yucatan & $70-80$ & Köhn, 2011 \\
\hline
\end{tabular}

pool due to the bottleneck effect (Ji et al., 2011). Interestingly, according to various estimates, the genetic diversity of laboratory pigs can be both greater and lower compared with similar parameters of pigs of factory breeds and wild boar (Nikitin et al., 2010; Heckel et al., 2015).

Several publications mentioned the existence of natural "contr inbred" mechanisms in natural populations (Charlesworth, Willis, 2009; Cheptou, Donohue, 2011; Mable, 2019), which is indirectly confirmed by the existence of the short populations of feral pigs with no signs of inbreeding depression on small islands throughout the centuries (Köhn, 2011; McKenney-Drake et al., 2016). In the conditions of farms for breeding of laboratory mini-pigs, the formation of the composition of the reproductive group and the choice of parent pairs during the breeding campaign is carried out by the breeder. Therefore, the question about the full functioning of such mechanisms arises. Thus, there is a need to analyze the methods available to humans to control herds' heterozygosity of laboratory mini-pigs. The first method is monitoring genetic diversity using molecular genetic methods, which is used to select some of the mini-pigs (Chang et al., 2009). A limiting factor in further implementing this method is the lack of data on its economic feasibility in routine use.

The second way to control heterozygosity is to use breeding techniques and methods, for example, to minimize inbred crosses (Simianer, Köhn, 2010). In the breeding of mini-pigs of the ICG SB RAS, the conservation of the maximum possible number of color phenotypes and inbreeding mainly on the progenitors is used to preserve genetic diversity (Nikitin et al., 2018). Given that the mammalian suit is controlled by 120 to 350 genes (Cieslak et al., 2011; Chandramohan et al., 2013), the number of possible genotypes can be in the thousands. Another breeding method for maximizing genetic diversity is dividing an array of animals into subpopulations with a limited gene flow between them (Mariani et al., 
Table 3. Conditional scheme of the selection of boars and sows during one cycle

\begin{tabular}{|c|c|c|c|c|c|}
\hline \multirow[t]{2}{*}{ Familia } & \multicolumn{4}{|c|}{ Line } & \multirow{2}{*}{$\begin{array}{l}\text { Minimum number } \\
\text { of sows in each } \\
\text { cycle }\end{array}$} \\
\hline & $\mathrm{B}_{1}$ & $B_{2}$ & $\mathrm{~B}_{3}$ & $\mathrm{~B}_{4}$ & \\
\hline $\mathrm{S}_{1}$ & I & II & III & IV & 5 \\
\hline $\mathrm{S}_{2}$ & II & I & IV & III & 5 \\
\hline $\mathrm{S}_{3}$ & III & IV & I & II & 5 \\
\hline $\mathrm{S}_{4}$ & IV & III & II & I & 5 \\
\hline $\begin{array}{l}\text { Minimum number } \\
\text { of hogs in every cycle }\end{array}$ & 2 & 2 & 2 & 2 & - \\
\hline
\end{tabular}

Note. The cells at the intersection of lines (columns) and families (rows) indicate the generations of descendants.

2020). However, due to the low number of rock formations, partial genealogical separation of lines, with rare exceptions (Stankova et al., 2017), is practically impossible to implement. Instead, a cyclical selection system is practiced (Chu, 2010; Schachler et al., 2020) based on periodically repeated crosses of lines and families (Table 3). According to the calculations, to avoid close inbreeding, the minimum number of the reproductive group should be at least 28 individuals, of which boars should be represented by at least four lines and sows - by four families. Each line should include at least one main and one checked boar, and the family should consist of at least 5 main and checked sows.

\section{Accumulation of genetic cargo}

In the 1970s, it was reported that in populations of less than 2,000 individuals, the probability of accumulation of fitnessreducing mutations is quite high (Nei, Roychoudhury, 1973). Even earlier, it was established that recessive semi-lethal mutations could persist in a population for up to 99 generations even with targeted culling of homozygotes (Dubinin, Glembotsky, 1967), which is generally not refuted by later mathematical modelling (Johnsson et al., 2019). It is considered that the elimination of harmful recessive mutations is a difficult task for the breeder, even if he uses modern genotyping methods (Derks et al., 2017). Given that the reproductive number of individual herds of laboratory mini-pigs does not exceed 3040 individuals reducing sustainability, semi-lethal and lethal recessive mutations pose a danger in breeding these animals. At the same time, in the entire history of breeding laboratory mini-pigs, only in the extinct breeding group Minisibs a decrease in the viability of young animals and the reproductive qualities of adults was described, the alleged cause of which was the accumulation of recessive mutations due to unilateral selection (Nikitin et al., 2014). Thus, laboratory mini-pigs' breeding system should include measures to purify the herd from harmful mutations, leading to strict selection in the reproductive group (Nikitin et al., 2018, 2020). Another method of cleaning herds from unwanted mutations is to assess the progeny in the inbred cross. This method was proposed for various farm animals' species in the 1950s and 1970s (Robertson, Rendel, 1950; Serebrovsky, 1970). However, despite its simplicity, the method has a serious drawback - it is the duration of the assessment and, accordingly, the cost of feeding and maintaining the tested boar and its descendants.

However, there are cases where breeders have benefited from the emergence of viability-reducing mutations in the herd in the form of creating model objects to optimize specific medical methods or treat strictly defined pathologies. Examples are the creation of mini-pigs by MeLiM and NIH (Sachs et al., 1976; Horak et al., 2019). Thus, it can be argued that the very fact of the occurrence of mutations that reduce viability, of course, is a danger. But much more important is breeders' ability to prioritize the selection of animals for reproduction and to carry out measures to clear the herds of genetic cargo; and if necessary, to consolidate the carriers of mutations in the form of a new selection group that is of value as a model object.

\section{The problem of white coat color in the breeding of laboratory mini-pigs}

It is known that when creating the first breeding groups of laboratory mini-pigs, the task was to create white-colored animals (Pond, Houpt, 1978), which were planned to be used as a biological model for studying the effects of radioactive radiation on the skin. However, despite the "influx of blood" of factory breeds of white color, attempts to consolidate it in herds of laboratory mini-pigs, as a rule, did not succeed. The exceptions are the Mini-Lewe pigs (Schachler et al., 2020) and the Bintang line (Lanyu 400) in the Lanyu mini-pig breeding group (Chu, 2010), but most herds have polymorphism by suit type (Mariano, 2003; Tikhonov, 2010; https://ameri canminipigassociation.com). Thus, the question arises about the factors that prevent the breeding of herds fully equipped with white individuals. It can be assumed that this is due to the dominant control of the most common type of white coat color (Pielberg et al., 2002), which is why there is a regular cleavage of pigmented piglets. Another explanation is that white piglets are born smaller and, therefore, less viable than colored animals (Nikitin et al., 2019). Despite this, the white coat color was successfully consolidated in a factory breeds series (Porter et al., 2016). It should be noted that the factory breeds of white-colored pigs were obtained by the method of more than 70 years of selection of white individuals in each generation with a preference for those animals in whose offspring there was no splitting according to the color phenotype (Porter et al., 2016). And this, in turn, is comparable to the duration of the oldest breeding groups of laboratory mini-pigs (Tikhonov, 2010). Thus, it can be assumed that the breeders of most breeding groups of mini-pigs simply did not have enough time to consolidate the white suit.

Molecular genetic typing of white animals would significantly speed up the process of fixing the white suit. It is known that the dominant white color of pigs is controlled by allele $I$ of the KIT gene (Pielberg et al., 2002; Wu et al., 2019). Thus, the first step to create a breeding group complete with all-white animals should be to cross white sows with white 
boars. All-white offspring from such crosses will need to be genotyped according to the KIT gene with the setting of homozygotes $(I / I)$ for rearing. The method of determining the KIT gene's alleles using real-time PCR is described in detail in the literature (Pielberg et al., 2002).

Another way is to consolidate the recessive white suit's phenotype, as demonstrated by the Lanyu 400 line (Chi, 2010) and the Chinese Rongchang breed (Lai et al., 2007). However, a rather serious restriction on using this method may be the low frequency of cleavage of recessive white color individuals, which in the herd of mini-pigs of the Institute of Cytology and Genetics SB RAS, according to zootechnical accounting, is about $1 \%$.

\section{Conclusion}

Over the past 10 years, facts have been discovered confirming the existence of 31 breeding groups of mini-pigs. Despite the lack of uniform selection standards in breeding laboratory mini-pigs, they adhere to such general criteria as a live weight of $50-80 \mathrm{~kg}$, normal viability, and the strength of the animals' constitution and exterior. Maintaining genetic diversity in herds of laboratory mini-pigs is possible both with the use of molecular genetic monitoring and purely selective methods. The minimization of the negative effect of genetic cargo accumulation in the herds of mini-pigs should be implemented mainly through a strict selection for fitness in the reproductive group. If necessary, due to the need for a specific type of biomedical experiments, it is possible to fix external and physiological characteristics in the herd, controlled by recessive mutations that reduce viability. Consolidation of white individuals is possible, which is proved by the examples of the Bintang line and the Mini-Lewe breeding group.

\section{References}

Bourneuf E. The MeLiM Minipig: An Original Spontaneous Model to Explore Cutaneous Melanoma Genetic Basis. Front. Genet. 2017; 8:146. DOI 10.3389/fgene.2017.00146.

Chandramohan B., Renieri C., La Manna V., La Terza A. The alpaca agouti gene: genomic locus, transcripts and causative mutations of eumelanic and pheomelanic coat color. Gene. 2013;521(2):303310. DOI 10.1016/j.gene.2013.03.060.

Chang W.H., Chu H.P., Jiang Y.N., Li S.H., Wang Y., Chen C.H., Chen K.J., Lin C.Y., Ju Y.T. Genetic variation and phylogenetics of Lanyu and exotic pig breeds in Taiwan analyzed by nineteen microsatellite markers. J. Anim. Sci. 2009;87(1):1-8. DOI 10.2527/ jas.2007-0562.

Charlesworth D., Willis J.H. The genetics of inbreeding depression. Nat. Rev. Genet. 2009;10:783-796. DOI 10.1038/nrg2664.

Cheng W., Zhao H., Yu H., Xin J., Wang J., Zeng L., Yuan Z., Qing Y., Li H., Jia B., Yang C., Shen Y., Zhao L., Pan W., Zhao H.Y., Wang W., Wei H.J. Efficient generation of GGTA1-null Diannan miniature pigs using TALENs combined with somatic cell nuclear transfer. Reprod. Biol. Endocrinol. 2016;14(1):77. DOI 10.1186/ s12958-016-0212-7.

Cheptou P.O., Donohue K. Environment-dependent inbreeding depression: its ecological and evolutionary significance. New Phytol. 2011;189(2):395-407. DOI 10.1111/j.1469-8137.2010.03541.x.

Chien S., Hsue S., Lin C., Kuo T., Wang D.J., Yang j.C., Lee S. Influence of Thread Design on Dental Implant Osseointegration As- sayed Using the Lan-Yu Mini-Pig Model. J. Med. Biol. Eng. 2017; 37:627-638. DOI 10.1007/s40846-017-0240-6.

Chu H.-P. Selection and Utilization of Minipigs for Biomedical Research. Taitung Animal Propagation Station, Livestock Research Institute, 2010;50. Available at: https://www.angrin.tlri.gov.tw/ meeting/2010training/12.Mr.H.P.Chu.pdf.

Cieslak M., Reissmann M., Hofreiter M., Ludwig A. Colours of domestication. Biol. Rev. Camb. Philos. Soc. 2011;86(4):885-899. DOI 10.1111/j.1469-185X.2011.00177.x.

Derks M.F.L., Megens H.J., Bosse M., Lopes M.S., Harlizius B., Groenen M.A.M. A systematic survey to identify lethal recessive variation in highly managed pig populations. BMC Genomics. 2017; 18(1):858. DOI 10.1186/s12864-017-4278-1.

Dubinin N.P., Glembotskiy Ya.L. Population Genetics and Selection. Moscow: Nauka Publ., 1967. (in Russian)

Heckel T., Schmucki R., Berrera M., Ringshandl S., Badi L., Steiner G., Ravon M., Küng E., Kuhn B., Nicole A Kratochwil N.A, Schmitt G., Kiialainen A., Nowaczyk C., Daff H., Khan A.P., Lekolool I., Pelle R., Okoth E., Bishop R., Daubenberger C., Ebeling M., Certa U. Functional analysis and transcriptional output of the Göttingenminipig genome. BMC Genomics. 2015;16:932. DOI 10.1186/s12864-015-2119-7.

Heining P., Ruysschaert T. The use of minipig in drug discovery and development: pros and cons of minipig selection and strategies to use as a preferred nonrodent species. Toxicol. Pathol. 2016;44(3): 467-473. DOI 10.1177/0192623315610823.

Helke K.L., Nelson K.N., Sargeant A.M., Jacob B., McKeag S., Haruna J., Vemireddi V., Greeley M., Brocksmith D., Navratil N., Stricker-Krongrad A., Hollinger C. Background Pathological Changes in Minipigs: A Comparison of the Incidence and Nature among Different Breeds and Populations of Minipigs. Toxicol. Pathol. 2016;44(3):325-337. DOI 10.1177/0192623315611762.

Horak V., Palanova A., Cizkova J., Miltrova V., Vodicka P., Kupcova Skalnikova H. Melanoma-Bearing LibechovMinipig (MeLiM): The Unique Swine Model of Hereditary Metastatic Melanoma. Genes (Basel). 2019;10(11):915. DOI 10.3390/genes10110915.

Itoh T., Kabawe M., Nagase T., Endo K., Miyoshi M., Miyahara M. Body surface area measurement in laboratory miniature pigs using a computer tomography scanner. J. Toxicol. Sci. 2016;41(5):637644. DOI 10.2131/jts.41.637.

Ji Y.Q., Wu D.D., Wu G.S., Wang G.D., Zhang Y.P. Multi-locus analysis reveals a different pattern of genetic diversity for mitochondrial and nuclear DNA between wild and domestic pigs in East Asia. PLoS One. 2011;6(10):e26416. DOI 10.1371/journal. pone.0026416.

Jo H., Lee S.C., Kim D.C., Kim B.G. Estimation of Growth Model Parameters for Mini Pig Breeds. The Faseb Journal. 2017;31(S1): ib299. DOI 10.1096/fasebj.31.1_supplement.lb299.

Johnsson M., Gaynor R.C., Jenko J., Gorjanc G., de Koning D.J., Hickey J.M. Removal of alleles by genome editing (RAGE) against deleterious load. Genet. Sel. Evol. 2019;51(1):14. DOI 10.1186/s12711-019-0456-8.

Ju Y.T., Pan Y.T., Tu C.F., Hsiao J., Lin Y.H., Yu P.J., Yu P.H., Chi C.H., Liu I.L. Growth and Behavior of Congenitally Anophthalmic LeeSung Pigs. Comp. Med. 2019;69(3):212-220. DOI 10.30802/ AALAS-CM-18-000095.

Kobayashi E., Hishikawa S., Teratani T., Lefor A.T. The pig as a model for translational research: overview of porcine animal models at Jichi Medical University. Transplant. Res. 2012;1:8. DOI 10.1186/2047-1440-1-8.

Köhn F. History and Development of Miniature, Micro- and Minipigs. The minipig in biomedical research. P.A. Mcanulty, A.D. Dayan, 
N.C. Ganderup, K.L. Hastings (Eds.). Boca Raton, FL: CRC Press, 2011;3-16. DOI 10.1201/b11356-3.

Lai F., Ren J., Ai H., Ding N., Ma J., Zeng D., Chen C., Guo Y., Huang L. Chinese white Rongchang pig does not have the dominant white allele of KIT but has the dominant black allele of MC1R. J. Hered. 2007;98(1):84-87. DOI 10.1093/jhered/es1053.

Mable B.K. Conservation of adaptive potential and functional diversity: integrating old and new approaches. Conservation Genetics. 2019;20:89-100. DOI 10.1007/s10592-018-1129-9.

Maeda M., Takashina S., Takasu M., Mori T., Goto N., Matsubara T., Almunia J., Imaeda N., Ando A., Kitagawa H. Magnetic Resonance Imaging of Ovarian Activity in Microminipigs Showing Normal Estrous Cycles. In vivo. 2016;30:35-40. Available at: http://iv.iiarjournals.org/content/30/1/35.full.

Mariani E., Summer A., Ablondi M., Sabbioni A. Genetic Variability and Management in Nero di Parma Swine Breed to Preserve Local Diversity. Animals (Basel). 2020;10(3):538. DOI 10.3390/ ani10030538.

Mariano M. Minisuíno (minipig) na pesquis abiomédica experimental. O Minipig br1. Acta Cir. Bras. 2003;18(5):387-391. DOI 10.1590/S0102-86502003000500003. (in Portuguese)

McKenney-Drake M.L., Rodenbeck S.D., Owen M.K., Schultz K.A., Alloosh M., Tune J.D., Sturek M. Repeat cross-sectional data on the progression of the metabolic syndrome in Ossabaw miniature swine. Data Brief. 2016;7:1393-1395. DOI 10.1016/j.dib. 2016.04.023

Miniature Swine Book of Normals. Sinclair Bio Resources, 2019. Available at: https://sinclairresearch.com/bio-resources/.

Nei M., Roychoudhury A.K. Probability of Fixation of Nonfunctional Genes at Duplicate Loci. Amer. Nat. 1973;107(955):362-372. DOI 10.1086/282840.

Nicholls S.M., Mitchard L.K., Laycock G.M., Harley R., Murrell J.C., Dick A.D., Bailey M. A Model of Corneal Graft Rejection in SemiInbred NIH Miniature Swine: Significant T-Cell Infiltration of Clinically Accepted Allografts. Invest. Ophthalmol. Vis. Sci. 2012; 53(6):3183-3192. DOI 10.1167/iovs.11-9106.

Nikitin S.V., Knyazev S.P., Shatokhin K.S. Miniature pigs of ICG as a model object for morphogenetic research. Russ. J. Genet.: Appl. Res. 2014;4(6):511-522. DOI 10.1134/S207905971406015X.

Nikitin S.V., Knyazev S.P., Shatokhin K.S., Zaporozhets V.I., Bashur D.S., Ermolaev V.I. Prenatal growth of live weight and coat color of the minipigs of ICG SB RAS. Sel'skokhozyaystvennye Tekhnologii = Agricultural Technologies. 2019;1(3):21-34. DOI 10.35599/agritech/01.03.04. (in Russian)

Nikitin S.V., Knyazev S.P., Shatokhin K.S., Zaporozhets V.I., Ermolaev V.I. Breeding and selection of mini-pigs in the ICG SB RAS. Vavilovskii Zhurnal Genetiki $i$ Selektsii $=$ Vavilov Journal of Genetics and Breeding. 2018;22(8):922-930. DOI 10.18699/ VJ18.434. (in Russian)

Nikitin S.V., Shatokhin K.S., Zaporozhets V.I., Kochnev N.N., Bashur D.S., Khodakova A.V., Ermolaev V.I. 'Genetic load' and changes in the chronology of early mortality in mini-pigs of ICG SB RAS. Agronomy Research. 2020;18(3):2156-2165. DOI 10.15159/AR.20. 171.

Nikitin S.V., Yudin N.S., Knyazev S.P., Aitnazarov R.B., Bekenev V.A., Deeva V.S., Goncharenko G.M., Kobzev V.F., Savina M.A., Ermolaev V.I. Differentiation of wild boar and domestic pig population based on the frequency of chromosomes carring endogenous retroviruses. Natural Science. 2010;2(6):527-534. DOI 10.4236/ns.2010. 26066.

Nunoya T., Shibua K., Saitoh T., Yazawa H., Nakamura K., Baba Y., Hirai T. Use of miniature pig for biomedical research, with refe- rence to toxicologic studies. J. Toxicol. Pathol. 2007;20:125-132. DOI 10.1293/TOX.20.125.

Pawlowsky K., Ernst L., Steitz J., Stopinski T., Kögel B., Henger A., Kluge R., Tolba R. The Aachen Minipig: Phenotype, Genotype, Hematological and Biochemical Characterization, and Comparison to the GöttingenMinipig. Eur. Surg. Res. 2017;58(5-6):193203. DOI $10.1159 / 000471483$.

Peripolli E., Munari D.P., Silva M.V.G.B., Lima A.L.F., Irgang R., Baldi F. Runs of homozygosity: current knowledge and applications in livestock. Anim. Genet. 2017;48(3):255-271. DOI 10.1111/ age. 12526.

Pielberg G., Olsson C., Syvanen A.C., Andersson L. Unexpectedly high allelic diversity at the KIT locus causing dominant white color in the domestic pig. Genetics. 2002;160:305-311.

Pond W.G., Houpt K.A. The Biology of the Pig. Ithaca, New York: Cornell University Press, 1978.

Porter V., Alderson L., Hall S.J.G., Sponenberg D.P. Mason's world encyclopedia of livestock breeds and breeding. Boston, MA: CABI, 2016.

Robertson A., Rendel J.M. The use of progeny testing with artifcial insemination in dairy cattle. J. Genet. 1950;50:1-31.

Protocol of testing for distinctness, uniformity, and stability. Pigs (Sus scrofa L.). All-Russia Research Institute of Animal Breeding, 2007. (in Russian)

Sachs D.H., Leight G., Cone J., Schwarz S., Stuart L., Rosenberg S. Transplantation in miniature swine. I. Fixation of the major histocompatibility complex. Transplantation. 1976;22(6):559-567. DOI 10.1097/00007890-197612000-00004.

Schachler K., Minx J-O., Sürie C., Distl O., Metzger J. Genetic characterisation of Mini-LEWE as resource population for experimental research. Berl. Munch. Tierarztl. Wochenschrt. 2020;133. DOI 10.2376/1439-0299-2020-15.

Scheffer J.P., Oliveira A.L.A., Markoski M., Antunes F., Atallah F.A., Monteiro G.A.S., Carvalho C.B., Kalil R.A.K. Indução da miocardiopatia isquêmica em modelo experimental mini porco. Rev. Bras. Med. Vet. 2013;35(1):45-48. (in Portuguese)

Serebrovskiy A.S. Genetic analisys. Moscow: Nauka Publ., 1970. (in Russian)

Shatokhin K.S., Nikitin S.V., Knyazev S.P., Goncharenko G.M., Ermolaev V.I., ZaporozhetsV.I. Livestock, physiology, and genetics of the mini-pigs of the Institute of Cytology and Genetics. Novosibirsk: Institute of Cytology and Genetics, 2019. (in Russian)

Simianer H., Köhn F. Genetic management of the Göttingen Minipig. J. Pharmacol. Toxicol. Methods. 2010;62:221-226. DOI 10.1016/ j.vascn.2010.05.004.

Simon C. Fachinformation aus dem Ausschuss für Ernährung der Versuchstiere. Fütterungskonzepte und -methoden in der Versuchstierhaltung und im Tierversuch - MINIPIG. Basel Reinhart Kluge, Potsdam-Rehbrücke. 2019;11. (in Germany). Available at: https:// docplayer.org/170135602-Fachinformation-aus-dem-ausschussfuer-ernaehrung-der-versuchstiere.html.

Smith A.C., Swindle M.M. Preparation of swine for the laboratory. ILAR J. 2006;47(4):358-63. DOI 10.1093/ilar.47.4.358.

Song T., Wu T., Wei F., Li A., Wang F., Xie Y., Liu D., Fan Z., Wang X., Cheng S., Zhang C., He J., Wang S. Construction of a cDNA library for miniature pig mandibular deciduous molars. BMC Dev. Biol. 2014;14:16. DOI 10.1186/1471-213X-14-16.

Stankova N.V., Savina M.A., Kapanadze G.D. The formation of new lines of Svetlogorsk minipigs. Biomeditsina = Biomedicine. 2017; 3:95-101. (in Russian)

Tikhonov V.N. Laboratory Minipigs. Genetics and Biomedical Use. Novosibirsk: Publishing House SB RAS, 2010. (in Russian) 
Val-Laillet D., Céline Tallet C., CaroleGuérin C., Meunier-Salaün M.-C. Behavioural reactivity, social and cognitive abilities of Vietnamese and Pitman-Moore weaned piglets. Appl. Anim. Behav. Sci. 2013;148:108-119. DOI 10.1016/j.applanim.2013.06.003.

Wu Z., Deng Z., Huang M., Hou Y., Zhang H., Chen H., Ren J. Whole-Genome Resequencing Identifies KIT New Alleles That Affect Coat Color Phenotypes in Pigs. Front. Genet. 2019;10:218. DOI 10.3389/fgene.2019.00218.

Xia J., Liu Z., Xin,L. Wang Z., Qian L., Wu S., Y. Shulin, Li K. Molecular characterization of swine leukocyte antigen class I genes by sequence-based and PCR-SSP method in Guizhouminipigs. Mol. Biol. Rep. 2014;41:7775-7782. DOI 10.1007/s11033-0143670-z.
Xin J., Yang H., Fan N., Zhao B., Ouyang Z., Liu Z., Zhao Y., Li X., Song J., Yang Y., Zou Q., Yan Q., Zeng Y., Lai L. Highly efficient generation of GGTA1 biallelic knockout inbred mini-pigs with TALENs. PLoS One. 2013;8(12):e84250. DOI 10.1371/journal. pone. 0084250 .

Yoshimatsu H., Konno Y., Ishii K., Satsukawa M., Yamashita S. Usefulness of minipigs for predicting human pharmacokinetics: Prediction of distribution volume and plasma clearance. Drug. Metab. Pharmacokinet. 2016;31(1):73-81. DOI 10.1016/j.dmpk.2015.11. 001.

Zhang S., Guo K., Kong D., Liu Y., Shang H., Wei H. Semen quality and fertility of Bama miniature pig (Sus scrofa domestica). Indian J. Anim. Res. 2016;(50):434-437. DOI 10.18805/ijar.7494.

ORCID ID

K.S. Shatokhin orcid.org/0000-0002-0885-2772

Acknowledgements. The study was carried out with the financial support of the Novosibirsk State Agrarian University.

Conflict of interest. The author declares no conflict of interest.

Received October 6, 2020. Revised February 2, 2021. Accepted February 10, 2021. 